\title{
Training and Development Costs, Staff Costs and Operational Profitability in Nepalese Commercial Banks
}

\begin{abstract}
The main aim of this study was to identify examine the relationship between staff trainings and development costs, total staff costs and the operational profit of Nepalese commercial banks. Six commercial banks has been taken for the study using purposive sampling technique from the total population consisting two government owned banks, two joint venture banks and the rest from private commercial banks. Training and development costs, staff costs and operational profit (before tax) has been defined as the variables of the study. Data have been collected from the annual reports of respective banks covering for the financial year 2016/2017 to 2019/2020. This study found that private commercial banks have focused on training and development to their staff. The staff costs of private banks has been highly explained by training and development costs and it has resulted higher positive impact of staff cost with operational profit.
\end{abstract}

Keywords: Training and development costs, staff costs, operational profitability, commercial banks.

\section{Introduction}

Human resources are the crucial resources for any type of organization and should be given the highest priority (Ojeleye \& Okoro, 2016). Robbins (2001) argued that a major feature that differentiates successful organizations from their contemporaries in almost all economic sectors is the quality of the people they are able to get and retain. Knowledge has, indeed, become power and organizations in our ever changing world consider knowledge and intellect of their employees as a competitive edge to compete effectively in the market place (Kharal, et al.,2014). Most of the companies take proactive measures for maintaining a reservoir of high technology staff, by continuous training and developments program of their staff. Therefore, money spent on employees' training and development is generally viewed as one of the critical investments that companies could make, and that such investments should be treated as a capital expenditure. Human capital is neither duplicated nor bought in the market. Training and development programs play a vital role in every organization. These programs improve employee performance at workplace. It updates employee knowledge and enhances their skills and helps in avoiding managerial obsolescence. Moreover it helps the employees in succession planning, and motivation. Training can provide abilities,

* Associate Professor, Central Department of Management, Tribhuvan University

E-mail id: adhikarinavaraj7@gmail.com 
knowledge and skills that enhance individual performance and it ultimately leads towards organizational performance. Furthermore Ahmad and Bakar (2003) suggested that employees who recognize the benefits of training tend to be more committed and so be more willing to participate in an organization's training activities. Barrett \& O'Connell (2001) emphasized the importance of effective training for organizational success. In this regard the importance of employees training in the workplace as training gives the impression of care and importance of employees and makes them loyal to the organization. Training and development provision creates a strong psychological bond between them and their employer (Garrow, 2004).

It provides employees with specific skills or correct deficiencies in their performance, while development is an effort to provide employees with abilities the organization will need in the future (Chew, 2004). Staff training and development costs is the component of staff costs associated with the staff training and development activities within the organization. Operational profit refers to an accounting metric measuring the profits a company generates from its core business functions, where the deduction of interest and taxes is excluded from the calculation. This indicator of profitability measures the operational efficiency of the business organization.

Staff costs constitute a major component of an organization's operational costs. Normally this costs includes salary/wages, allowances, contribution to provident fund, training and development expenses, uniform allowance, medical allowance, insurance premium paid by employer on behalf of employee, pension and gratuity etc. It impacts the overall operational profitability of the business due to its running nature. The amount of staff costs incurred by organizations dependents on the organizational policy, management's placement on the welfare of its employees and a number of other variables affecting the entity. Budhathoki \& Rai (2018) revealed that Nepalese commercial banks cannot increase the net profit by increasing their staff salary and argued that banks should cut their staff expenses in order to increase the net profit. Operational profit and net profit are the different parameters for measuring the profitability. Training and development costs is the part of staff costs and the staff costs is a major component of operational costs. Therefore this study aims:

1. To examine the relationship between staff trainings and development costs on total staff costs in Nepalese commercial banks.

2. To identify the impact of staff trainings and development costs on total staff costs in Nepalese commercial banks.

3. To identify the impact of total staff costs on operational profit.

\section{Methodology and Results}

This study has followed descriptive as well as causal comparative design. Out of the 27 commercial banks under population of commercial banks, only 6 commercial banks has been taken for the study using purposive sampling technique consisting 2 from government owned banks 2 from joint venture banks and the rest from private commercial banks. The study has focused to identify the relationship between relationship between training and 
development costs and staff costs and staff costs and operational profitability of the sample banks. Therefore training and development costs, staff costs and operational profit (before tax) has been taken as the variables of the study. The data required for the study have been collected from the annual reports of respective banks covering for the financial year 2016/2017 to 2019/2020. Descriptive as well as inferential statistics have been applied for the analysis of relevant information. Linear regression model have been applied having dependent and independent variables. Regression models:

ST $\_$C $=\beta_{0}+\beta_{1} \mathrm{TDC}+\ldots+$ et. ..... (I)

$\mathrm{OP}_{-} \mathrm{P}=\beta_{0}+\beta_{1} \mathrm{STC}+\ldots+$ et........(II)

Where: $S T \_C=$ Staff costs, STC $=$ Staff costs, TDC $=$ Training and development costs, OP_P $=$ Operational profit and et $=$ error term.

Table 1 Statistics of sample banks

\begin{tabular}{llcc}
\hline \multicolumn{1}{c}{ Status of banks } & \multicolumn{1}{c}{ Name of banks } & Frequency & Percentage (\%) \\
\hline Government owned banks & Nepal Bank Limited & 2 & 33.33 \\
& $\begin{array}{l}\text { Rastriya Banijya Bank Limited } \\
\text { Nabil Bank Limited }\end{array}$ & 2 & 33.33 \\
Joint venture banks & Nepal Investment Bank Limited & & \\
NiCASIA Bank Limited & 2 & 33.33 \\
Private banks & Global IME Bank Limited & & 100 \\
\hline & Total & 6 &
\end{tabular}

Table 1 presents the sample banks taken for the study. All categories of commercial banks are taken for the study.

Table 2 Descriptive Statistics of Training and Development Costs

\begin{tabular}{ccc}
\hline Status of banks & Mean & Std. Deviation \\
\hline Government owned banks & 28222949.1250 & 10986769.20310 \\
Joint venture banks & 23133688.8750 & 8055479.51321 \\
Private banks & 33657228.2500 & 20741625.90486 \\
All sample banks & 28337955.4167 & 14376675.69286 \\
\hline
\end{tabular}

Table 2 highlights the mean value of training and development costs of sample banks. The results indicates that the mean value of all sample banks is 28337955.4167 . Private commercial banks have higher mean value of training and development costs than government owned 
banks and joint venture banks. It shows that private commercial banks have focused on training and development of their staff.

Table 3 Descriptive Statistics of Staff Costs

\begin{tabular}{ccc}
\hline Status of banks & Mean & Std. Deviation \\
\hline Government owned banks & 2590212181.6250 & 472147258.14138 \\
Joint venture banks & 1587200152.3750 & 293206278.84324 \\
Private banks & 1843004157.7500 & 695761072.17193 \\
All sample banks & 2006805497.2500 & 655973821.16568 \\
\hline
\end{tabular}

Table 3 shows the mean value of staff costs. The government owned commercial banks have greater mean value (2590212181.6250) of staff costs than the mean value (2006805497.2500) of sample banks. It indicates that joint venture and private banks have low level of staff costs than government owned banks.

Table 4 Descriptive Statistics of Operational Profit

\begin{tabular}{ccc}
\hline Status of banks & Mean & Std. Deviation \\
\hline Government owned banks & 4588946537.8750 & 1236745319.15087 \\
Joint venture banks & 4914834057.8750 & 806795965.67601 \\
Private banks & 3357748807.3750 & 1085480821.26778 \\
All sample banks & 4287176467.7083 & 1221224106.27828 \\
\hline
\end{tabular}

Table 4 presents the operational profit of sample banks. The results shows that joint venture commercial banks have greater mean value (4914834057.8750) of operational profit than government owned banks and private banks.

Table 5 Degree of Correlations

\begin{tabular}{|c|c|c|c|}
\hline & T\&D costs GOVT & Staff costs GOVT & $\begin{array}{l}\text { Operational } \\
\text { Profit GOVT }\end{array}$ \\
\hline T\&D costs GOVT & 1 & & \\
\hline Staff costs GOVT & $.503^{*}$ & 1 & \\
\hline Operational Profit GOVT & $.661^{*}$ & $.577^{*}$ & 1 \\
\hline
\end{tabular}

*. Correlation is significant at the 0.05 level

Table 5 indicates the relationship between training and development costs, staff costs and operational profit of government owned banks. The result shows the moderate degree $(.5<.503, .577)$ of positive relationship between training and development costs and staff costs as well as staff costs and operational profit. 
Table 6 Degree of Correlations

\begin{tabular}{lccc}
\hline & T\&D costs JVT & Staff costs JVT & Operational Profit JVT \\
T\&D costs JVT & 1 & & \\
Staff costs JVT & $.622^{*}$ & 1 & 1 \\
Operational Profit JVT & $.469^{*}$ & $.520^{*}$ & 1 \\
\hline
\end{tabular}

*. Correlation is significant at the 0.05 level

Table 6 highlights the relationship between training and development costs, staff costs and operational profit government of joint venture banks. The result shows the moderate degree $(.5<.622, .520)$ of positive relationship between training and development costs and staff costs as well as staff costs and operational profit.

Table 7 Degree of Correlations

T\&D costs PVT Staff costs PVT $\quad$ Operational Profit

PVT

T\&D costs PVT

1

Staff costs PVT

$.716^{*}$

1

Operational Profit PVT

.425

$.745^{*}$

1

*. Correlation is significant at the 0.05 level

Table 7 shows the relationship between training and development costs, staff costs and operational profit of private commercial banks. The result shows the strong degree $(.7<.716$, .745) of positive relationship between training and development costs and staff costs as well as staff costs and operational profit.

Table 8 Degree of Correlations

\begin{tabular}{lccc}
\hline & T\&D costs all & Staff costs all & Profit all \\
T\&D costs all & 1 & & \\
Staff costs all & .511 & 1 & \\
$:$ Operational Profit all & .211 & $.417^{*}$ & 1 \\
\hline
\end{tabular}

*. Correlation is significant at the 0.05 level

Table 8 presents the relationship between training and development costs, staff costs and operational profit of all sample banks. The result shows the moderate degree $(.5<511)$ of 
positive relationship between training and development costs and staff costs as well as weak degree $(.5>.417)$ of relationship between staff costs and operational profit.

Table 9 Regression results

\begin{tabular}{llcccc}
\hline \multirow{3}{*}{ Government Owned } & Coefficients & 1980234706.461 & $\beta_{1}$ & $\mathrm{~F}$ & R Square \\
& Sig. & 0.005 & 0.204 & 2.031 & .253 \\
Joint Venture & Coefficients & 1063131249.109 & 22.654 & 0.204 & \\
\multirow{2}{*}{ Private } & Sig. & 0.009 & 0.099 & 0.099 & .387 \\
& Coefficients & 1034193280.294 & 24.031 & 6.326 & .531 \\
& Sig. & 0.000 & 0.046 & 0.046 & \\
\hline
\end{tabular}

Dependent Variable: Staff costs, Predictors: (Constant), T\&D costs

Table 9 presents regression results of staff costs as dependent variable and training and development costs as predictor in all types of banks. The training and development costs revealed positive impacts on staff costs on all types of banks. Staff costs is explained by $53.1 \%, 38.7 \%$ and $25.3 \%$ with training and development costs in private, joint venture and government banks respectively.

Table 10 Regression results

\begin{tabular}{ccclc}
\hline & $\beta_{0}$ & $\beta_{1}$ & $F$ & R Square \\
\hline Coefficients & 1345819460.179 & 23.325 & 7.783 & 0.261 \\
Sig. & 0.032 & 0.011 & 0.011 & \\
\hline
\end{tabular}

Dependent Variable: Staff costs all sample banks, Predictors: (Constant), T\&D costs all sample banks

Table 10 reveals the regression results of staff costs as dependent variable and training and development costs as predictor in all sample banks. The training and development costs indicated positive impacts on staff costs on all types of banks. Staff costs is explained by $26.1 \%$, with training and development costs in all sample banks .

Table 11 Regression results

\begin{tabular}{lccccc}
\hline & & $\beta_{0}$ & $\beta_{1}$ & $F$ & R Square \\
Government Owned & Coefficients & 673397289.896 & 1.512 & 2.996 & .333 \\
& Sig. & 0.779 & 0.134 & 0.134 & \\
Joint Venture & Coefficients & 2643289055.000 & 1.431 & 2.225 & .271 \\
\multirow{2}{*}{ Private } & Sig. & 0.138 & 0.186 & 0.186 & \\
& Coefficients & 1214251738.360 & 1.163 & 7.506 & .556 \\
& Sig. & 0.194 & 0.034 & 0.034 & \\
\hline
\end{tabular}


Dependent Variable: Operational Profit, Predictors: (Constant), Staff costs

Table 11 presents regression coefficients of operational profit as dependent variable and staff costs as predictor in three type's banks. The staff costs indicates positive impacts on operational profit on all types of banks. Operational profit is explained by $55.6 \%, 33.3 \%$ and $27.1 \%$ with staff costs in private, government and joint venture banks respectively.

Table 12 Regression results

\begin{tabular}{ccccc}
\hline & $\beta_{0}$ & $\beta_{1}$ & $F$ & R Square \\
\hline Coefficients & 2729765948.055 & .776 & 4.627 & .174 \\
Sig. & 0.002 & 0.043 & 0.043 & \\
\hline
\end{tabular}

Dependent Variable: Operational Profit all sample banks, Predictors: (Constant), Staff costs all sample banks

Table 12 reveals the regression results of as operational profit dependent variable and staff costs as predictor in all sample banks. As per the result staff costs indicated positive impacts on operational profit on all types of banks. Operational profit is explained by $17.4 \%$, with training and staff costs in all sample banks.

\section{Conclusion}

The main aim of this study was to examine the relationship between staff trainings and development costs, total staff costs and the operational profit of Nepalese commercial banks. This study identified that private commercial banks have focused on training and development of their staff rather than other sample banks. Similarly staff costs revealed high in government owned banks while operational profit revealed high in joint venture banks. Additionally the staff costs of private banks has been highly explained by training and development costs and it has resulted higher positive impact of staff cost with operational profit and it differs from the line of Budhathoki \& Rai (2018). In addition this study can be used for further research regarding cross banking sector. 


\section{References}

Ahmad, K.Z. \& Bakar, R.A. (2003). The Association between training and organizational commitment among white collar workers in Malaysia. International Journal of Training and Development, 7(3), 166-185.

Barrett, A., \& O'Connell, P. J. (2001). Does training generally work? Measuring the returns. Industrial and Labor Relations Review, 54 (3), 647-662.

Budhathoki, P. B. \& Rai, C. K. (2018). Staff expenses and its effect on bank's net profit. Researcher, 3(3), 63-71.

Chew, J. (2004). Managing MNC Expatriates through Crises: A Challenge for International Human Resource

Management, Research and Practice in Human Resource Management, 12(2), 1-30

Chew, J. (2004). Managing MNC Expatriates through Crises: A Challenge for International Human Resource

Management, Research and Practice in Human Resource Management, 12(2), 1-30

Chew, J. (2004). Managing MNC expatriates through crises: A challenge for international human resource management. Research and Practice in Human Resource Management, 12(2), 1-30.

Garrow, V. (2004). Training and development and the psychological contract. Training Journal, April, 8-10.

Global IME Bank. (2020). Annual report. Retrieved from https:/ / globalimebank.com/assets/ upload/reports/annual-report-2076-77-(global-ime-bank-limited---in-nepali).pdf

Global IME Bank. (2018). Annual report. Retrieved from https:/ /globalimebank.com/assets/ upload/reports/annual-report-2074-2075-[in-english].pdf

Hameed, A. \& Waheed, A. (2011). Employee development and its effect on employee performance: A conceptual framework. International Journal of Business and Social Science, 2 (13), 224-229.

Hamid, S. (2011). A study of effectiveness of training and development programmes of UPSTDC, India - An analysis. South Asian Journal of Tourism and Heritage, 4 (1), $72-$ 82.

Hutchings, K., Zhu, C.J., Cooper, B. K., Zhang, Y. \& Shao, S. (2009). Perceptions of the effectiveness of training and development of grey-collar workers in the People's Republic of China. Human Resource Development International, 12(3), 279-296. 
Kharal, M., Zai-ur-Rehman, M., Abrar, M.. \& Khan, M.S. (2014). Intellectual capital and firm performance: An empirical study on the oil and gas sector of Pakistan. International Journal of Accounting and Financial Reporting, 4(1), 239-259

Khawaja \& Nadeem (2013). Training and development program and its benefits to employee and organization: A conceptual study. European Journal of Business and Management, 5 (2), 243-252.

Nabil Bank Limited. (2020). Annual report. Retrieved from https://nabilbank.com//images/ pdf/uploaded/Annual $\% 20$ Report $\% 20$ Nepali $\% 20-\% 20 \mathrm{FY} \% 202076$ 77\% $\quad 20(\% 20$ 2019_20\%20).pdf

Nabil Bank Limited. (2018). Annual report. Retrieved from https:/ / nabilbank.com/ / images/ pdf/uploaded/Annual\%20Report\%20_.pdf

Nepal Bank Limited. (2020). Annual report. Retrieved from http://www.nepalbank.com. $\mathrm{np} /$ assets/upload/files/Annual\%20Report\%202076-77.pdf

Nepal Bank Limited. (2018). Annual report. Retrieved from https://www.nepalbank.com. $\mathrm{np} /$ assets/upload/downloads/-audited-financial-results-(ashad-end-2074)-[english-version-].pdf

Nepal InvestmentBankLimited.(2020). Annual report. Retrieved from https:/ / www.nibl.com. np/public/Uploads/Documents/637456377791894344_Annual_Report_2019_2020. $\mathrm{pdf}$

Nepal Investment Bank Limited. (2018). Annual report. Retrieved from https://www.nibl. com.np/public/Uploads/Documents/637293764925973237_Annual_Report_201718_English.pdf

NICASIA Bank Limited. (2020). Annual report. Retrieved from https://www.nicasiabank. com/assets/backend/uploads/Financial\%20Highlights/76-77/Annual\%20Report2076-77.pdf

NICASIA Bank Limited. (2018). Annual report. Retrieved from https://www.nicasiabank. com/assets/backend/uploads/Annual\%20reports/NIC\%20Asia\%20Bank/ NIC\%20ASIA \%20English\%20Annual\%20Report\%202017.18.pdf

Ojeleye, Y.C \& Okoro, C.I. (2016). Job stress and employees' productivity in telecommunication sector of Nigeria (A study of Globacom, MTN, Airtel and Etisalat). International Journal of Multidisciplinary Education and Research, 1 (5), 5-10.

Rastriya Banijya Bank. (2020). Fourth quarter report. Retrieved from https://www.rbb.com. np/ uploads/images/report/1589282304-405316.pdf

Rastriya Banijya Bank. (2018). Annual report Retrieved from https://www.rbb.com.np/ uploads/images/report/1589282304-405316.pdf 
Robbins, S. P. (2001), Organizational Behaviour 9th Edition. Singapore: Pearson Education (Singapore) Ltd.

Rohan, S. \& Madhumita, M. (2012). Impact of training practices on employee productivity: A comparative study. Inter science Management Review, 2 (2), 87-92.

Satterfield JM, Hughes E. (2007). Emotion skills training for medical students: a systematic review. Medical Education, 41(1), 935-941. 